\title{
Studies on the sulfur metabolism of cows on protein-free and low-protein feed
}

\author{
Eino Matikkala and Matti Kreula \\ Biochemical Research Institute, Kalevankatu 56 b, SF-00180 Helsinki 18, Finland
}

\begin{abstract}
The influence of purified, protein-free feed with urea and ammonium salts as nitrogen sources ( 0 -feed) and of non-purified, urea-rich, low-protein feeds (ULP-feed) on the sulfur metabolism of cows has been studied by determining the contents of sulfur fractions in faeces, urine, milk, blood and rumen fluid. The sulfur of 0 -feed was composed entirely of inorganic sulfate. During balance trials the $\mathrm{N}: \mathrm{S}$ ratio in the feed varied from 6.1 to 9.5 , and the sulfur content from 0.22 to $0.31 \%$ of the dry matter. In every trial (seven with 0 -feed and two with ULP-feed), of five or seven days duration, the cows were in high-positive sulfur balance. The 0 -cows excreted a greater proportion of their total sulfur output via urine than the ULP-cows. The excretion of inorganic sulfate sulfur, as a proportion of the urinary and faecal sulfur, was greater for 0 -cows than for ULP- or NorP-cows (cows on normal, protein-rich feed); the opposite was the case with regard to the excretion of ester sulfate sulfur and neutral sulfur. The sulfur contents of milk and blood showed only minor inter-feed differences.

The sulfate content in the rumen fluid of the 0 -cow rose rapidly after the commencement of feeding and then fell quite rapidly. We conclude tentatively that in the rumen of the 0 -cow hydrogen sulfide is generated so quickly that the whole of it cannot be used for the synthesis of sulfur-containing compounds, a considerable proportion of it being lost in eructations or excreted as inorganic sulfates in the urine.
\end{abstract}

\section{Introduction}

Long-term feeding experiments with dairy cows, which Virtanen started in 1961, have shown that cows on purified, protein-free feed with urea and ammonium salts as the sole sources of nitrogen (0-cows) consume less feed during the first three months of the lactation, and yield less milk than cows on low-protein, urea-rich feed (ULP-cows) or on normal, protein-rich feed (NorP-cows) (Virtanen et al. 1972, Ettala and Kreula 1976). The amounts of certain free amino acids in the blood plasma of 0 - and ULP-cows are much lower than the corresponding values in NorP-cows. However, the differences in milk production between 0- and ULP-cows are difficult to explain on the basis of the lack of certain free amino acids in the plasma (VIRTANEN et al. 1972). Also the total lipid content in the blood plasma of 0 -cows is only about $1 / 3$ of normal (Virtanen et al. 1972, Homer and Virtanen 1973). Therefore it has been suggested that disturbances in lipid metabolism may be responsible in part for the reduced appetite and milk production of 0 -cows during the main milk production period (VIRTANEN et al. 1972). 
Little attention has been paid previously to the sulfur metabolism of 0 and ULP-cows. We have now measured the excretion of sulfur and its contents in milk, blood, plasma and rumen fluid of 0 -, ULP- and to some extent also of NorP-cows. By these means we have tried to indicate possible anomalies in the utilization of sulfur in 0 -cows.

\section{Materials and Methods}

The feed of 0- and ULP-cows (Ayrshire breed) has been described earlier (Virtanen 1967, Virtanen et al. 1972, Ettala and Kreula 1976). The composition of the feed varied to some extent from one balance trial to another. Therefore we give in table 1 the contents of carbohydrates, nitrogen, and sulfur and nitrogen to sulfur ratio in the feed during the trials, in which the urine and faeces of the cows were collected for balance studies. 0-cows received nitrogen as urea and ammonium salts, and sulfur as inorganic sulfates. The sulfates of the mineral mixture accounted for $32 \%$ of the total feed sulfur, and urea 58 and $57 \%$ of the total feed nitrogen, during trials I and II with ULP-cow Euru. The average daily milk production and secretion of urine and faeces are given in table 2 .

Most of the faeces and urine samples from the 0- and ULP-cows had been collected earlier during the series of balance trials. In trial V with 0 -cow Oona the sample collection period was seven days; in all other trials it was five days. The samples of faeces were dried at $80^{\circ} \mathrm{C}$ and then ground. Samples from NorPcows were obtained from the Department of Animal Husbandry, University of Helsinki (urine, blood and rumen contents), from the Agricultural Research Centre, Department of Animal Husbandry, Tikkurila, Finland (faeces) and from one farm in Northern Finland (blood samples). Potassium oxalate (2 $\mathrm{mg} / \mathrm{ml}$ ) was used as the anticoagulant for blood samples, from which plasma was prepared by centrifugation. All samples were preserved frozen before analysis. Samples of the rumen contents of fistulated cows were taken at twohour intervals, starting when the cow began to feed, and were frozen immediately. Cold, melted samples were centrifuged at $28700 \mathrm{~g}$ for 30 minutes; it is possible that the content of sulfate sulfur decreased slightly during this treatment.

Sulfur in its various forms was determined by modifications of the methods of BIRD and Fountain (1970). Neutral sulfur was obtained as the difference between total sulfur and total sulfate sulfur; and inorganic sulfate sulfur as the difference between total sulfate sulfur and ester sulfate sulfur.

\section{Results and Discussions}

\section{Sulfur balance and sulfur in urine and faeces}

Dietary nitrogen and sulfur requirements of ruminants are interdependent and are related also to the other ingredients of the feed, the physiological state of the animals, and the form of nitrogen and sulfur in the feed. Therefore a generally accepted figure for the optimum level of sulfur in feed cannot be given. A suitable sulfur content in the feed of lactating cows is estimated 
Table 1. Composition of diets fed to 0- and ULP-cows during balance trials.

\begin{tabular}{|c|c|c|c|c|c|c|c|}
\hline \multirow{2}{*}{\multicolumn{2}{|c|}{$\begin{array}{l}\text { Cow and } \\
\text { number of } \\
\text { trial }\end{array}$}} & \multicolumn{3}{|c|}{$\begin{array}{l}\text { Carbohydrate composition, } \\
\% \text { of total carbohydrates }\end{array}$} & \multirow{2}{*}{$\begin{array}{l}\text { Sulfur content, } \\
\% \text { of dry } \\
\text { matter }\end{array}$} & \multirow{2}{*}{$\begin{array}{l}\text { Nitrogen content } \\
\% \text { of dry } \\
\text { matter }\end{array}$} & \multirow[t]{2}{*}{$\mathrm{N} / \mathrm{S}$} \\
\hline & & Starch & Cellulose & Sucrose & & & \\
\hline \multicolumn{8}{|c|}{ 0-cow Oona: } \\
\hline I & ................... & 53.5 & 21.0 & 25.6 & 0.27 & 2.40 & 8.8 \\
\hline II & .................... & 53.4 & 21.0 & 25.6 & 0.28 & 2.40 & 8.5 \\
\hline III & ................... & 53.2 & 21.1 & 25.7 & 0.31 & 2.47 & 7.9 \\
\hline IV & ................... & 51.7 & 25.4 & 22.9 & 0.31 & 2.70 & 8.8 \\
\hline V & n.................. & 50.9 & 25.5 & 23.6 & 0.30 & 1.84 & 6.1 \\
\hline \multicolumn{8}{|c|}{ 0-cow Voona: } \\
\hline I & ................... & 47.9 & 27.7 & 24.4 & 0.22 & 1.91 & 8.6 \\
\hline II & .................... & 52.0 & 22.5 & 25.5 & 0.27 & 2.29 & 7.7 \\
\hline \multicolumn{8}{|c|}{ ULP-cow Euru: } \\
\hline I & ……............ & & & & 0.29 & 2.75 & 9.4 \\
\hline II & ................... & & & & 0.28 & 2.71 & 9.5 \\
\hline
\end{tabular}

to be $0.20 \%$ of the dry matter (ELAM 1975) and the best nitrogen to sulfur ratio is about 13.5 to $15: 1$ (BRAY and TILL 1975). On the basis of the sulfur contents and N:S ratios (Table 1) in their feeds, 0- and ULP-cows received adequate amounts of sulfur in their diets. Moderate rates of excretion, in faeces and urine, of inorganic sulfate sulfur (Table 2, Fig. 1) also show that

Table 2. Intake of sulfur in feed, excretion of sulfur in urine, faeces and milk, and sulfur balance of cows on 0 - or ULP-diet.

\begin{tabular}{|c|c|c|c|c|c|c|c|c|c|}
\hline \multirow[b]{2}{*}{ Number of trial } & \multicolumn{5}{|c|}{0 -cow Oona } & \multicolumn{2}{|c|}{ 0-cow Voona } & \multicolumn{2}{|c|}{ ULP-cow Euru } \\
\hline & I & II & III & IV & V & I & II & I & II \\
\hline \multicolumn{10}{|l|}{ Intake in feed } \\
\hline 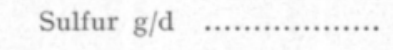 & 27.7 & 28.5 & 30.3 & 26.2 & 19.8 & 12.9 & 23.4 & 29.4 & 30.2 \\
\hline \multicolumn{10}{|l|}{ Urinary excretion } \\
\hline Urine $\mathrm{kg} / \mathrm{d}$................. & 18.7 & 13.4 & 10.7 & 16.1 & 15.5 & 10.3 & 20.6 & 10.4 & 12.3 \\
\hline Total sulfur $\mathrm{g} / \mathrm{d}$............. & 12.2 & 14.4 & 6.9 & 10.2 & 8.9 & 5.8 & 15.7 & 12.6 & 11.2 \\
\hline Total sulfate sulfur $\mathrm{g} / \mathrm{d}$. & 11.4 & 13.4 & 6.3 & 9.6 & 8.3 & 5.4 & 14.4 & 11.4 & 10.2 \\
\hline $\begin{array}{l}\text { Ester sulfate sulfur g/d ... } \\
\text { Inorganic sulfate sulfur }\end{array}$ & 0.77 & 0.52 & 0.27 & 0.43 & 0.28 & 0.26 & 0.72 & 2.54 & 2.00 \\
\hline 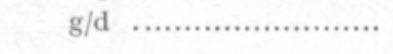 & 10.6 & 12.8 & 6.1 & 9.2 & 8.0 & 5.2 & 13.7 & 8.8 & 8.2 \\
\hline \multicolumn{10}{|l|}{ Faecal excretion } \\
\hline Faeces kg/d $\ldots . \ldots \ldots \ldots . . . . . .$. & 2.7 & 2.3 & 2.3 & 2.3 & 1.2 & 1.5 & 2.1 & 3.1 & 2.9 \\
\hline Total sulfur $\mathrm{g} / \mathrm{d}$............. & 3.3 & 3.2 & 3.0 & 3.6 & 1.8 & 2.0 & 3.0 & 7.7 & 7.6 \\
\hline Total sulfate sulfur $\mathrm{g} / \mathrm{d} \ldots$ & 0.66 & 0.64 & 0.52 & 0.65 & 0.24 & 0.39 & 0.77 & 1.32 & 1.45 \\
\hline Ester sulfate sulfur $\mathrm{g} / \mathrm{d} \ldots$ & 0.11 & 0.07 & 0.15 & 0.09 & 0.05 & 0.08 & 0.18 & 0.60 & 0.58 \\
\hline $\begin{array}{l}\text { Inorganic sulfate sulfur } \\
\text { g/d } \ldots \ldots \ldots \ldots \ldots \ldots \ldots \ldots \ldots \ldots \ldots \ldots \ldots \ldots \ldots \ldots\end{array}$ & 0.55 & 0.57 & 0.37 & 0.57 & 0.20 & 0.31 & 0.59 & 0.71 & 0.86 \\
\hline Milk kg/d ....................... & 11.3 & 6.3 & 7.4 & 6.2 & 3.9 & 4.8 & 4.8 & 11.1 & 9.4 \\
\hline Total sulfur $\mathrm{g} / \mathrm{d}$............. & 4.0 & 2.2 & 2.6 & 2.2 & 1.4 & 1.7 & 1.8 & 3.4 & 2.9 \\
\hline Total sulfate sulfur $\mathrm{g} / \mathrm{d} \ldots$ & 0.29 & 0.16 & 0.19 & 0.16 & 0.10 & 0.13 & 0.15 & 0.35 & 0.30 \\
\hline Sulfur balance $\mathrm{g} / \mathrm{d} \ldots \ldots \ldots$ & +8.2 & +8.6 & +17.8 & +10.2 & +7.8 & +3.4 & +2.9 & +5.7 & +8.5 \\
\hline
\end{tabular}


the cows probably obtained more sulfur than their requirements for protein synthesis and sulfation reactions. In contrast, the feed of NorP-cows sometimes contained little or no extra sulfur, because the concentration of inorganic sulfate sulfur in their urine and faeces was low on occasion (Table 3, Fig. 1).

Although some ruminal bacteria in pure culture do not grow on inorganic sulfate, it is considered that due to symbiotic relationships among the microorganisms in the rumen the form of sulfur in feed has little significance (WHANGER 1972). However, inorganic sulfates should favour the growth of dissimila-
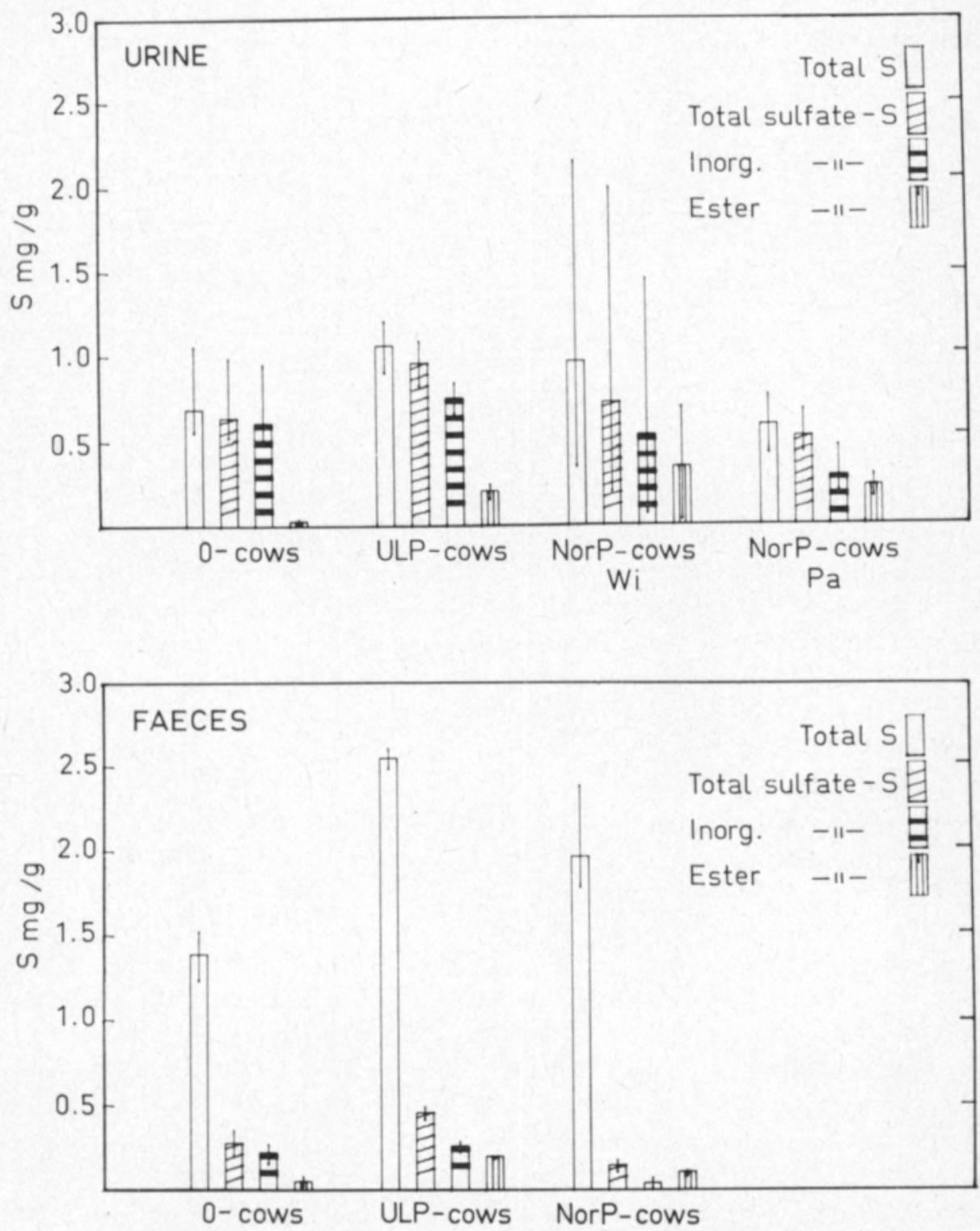

Figure 1. Contents of sulfur fractions in urine and dried faeces of 0-, ULP- and NorP-cows. The columns show the mean contents, and the lines their variations. The contents in urines of NorP-cows are expressed separately on winter rations (Wi) and on pasture $(\mathrm{Pa})$. 
Table 3. Contents of total sulfur and total sulfate, ester sulfate and inorganic sulfate sulfur in urine and dried faeces of NorP-cows. The range of contents is given below the means.

\begin{tabular}{|c|c|c|}
\hline & Winter rations & Pasture \\
\hline Urine: & $\mathrm{n}=12$ & $\mathrm{n}=5$ \\
\hline 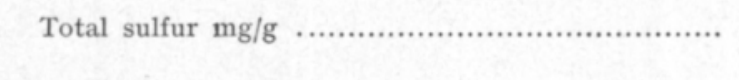 & $\begin{array}{l}0.96 \\
0.35-2.16\end{array}$ & $\begin{array}{l}0.60 \\
0.48-0.77\end{array}$ \\
\hline 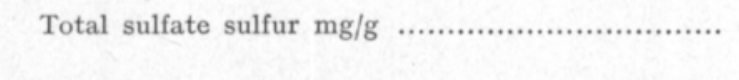 & $\begin{array}{l}0.73 \\
0.20-2.00\end{array}$ & $\begin{array}{l}0.52 \\
0.43-0.68\end{array}$ \\
\hline 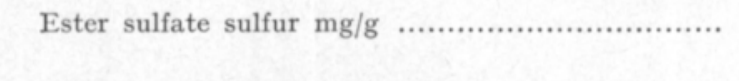 & $\begin{array}{l}0.34 \\
0.04-0.70\end{array}$ & $\begin{array}{l}0.23 \\
0.16-0.30\end{array}$ \\
\hline 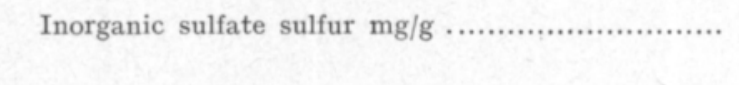 & $\begin{array}{l}0.53 \\
0.07-1.46\end{array}$ & $\begin{array}{l}0.29 \\
0.18-0.47\end{array}$ \\
\hline Faeces: & $\mathrm{n}=6$ & \\
\hline 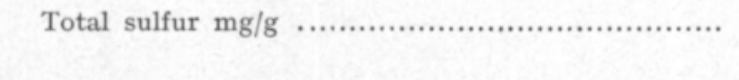 & $\begin{array}{l}1.97 \\
1.79-2.39\end{array}$ & \\
\hline 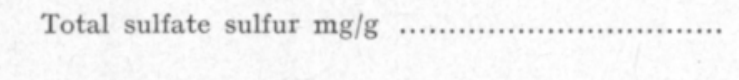 & $\begin{array}{l}0.15 \\
0.11-0.18\end{array}$ & \\
\hline 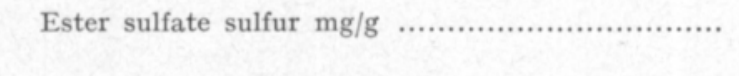 & $\begin{array}{l}0.11 \\
0.09-0.12\end{array}$ & \\
\hline 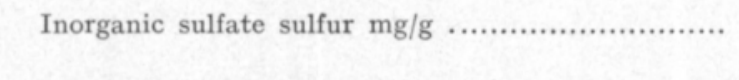 & $\begin{array}{l}0.04 \\
0.00-0.07\end{array}$ & \\
\hline
\end{tabular}

tory sulfate-reducing bacteria in the rumina of 0 -cows. Further, their number is not controlled by protozoa. We did not have the technical means of measuring the hydrogen sulfide contents in the rumen, but in our opinion some results of this study indicate that its generation in the rumina of 0 -cows may have been copious. We suspect losses of hydrogen sulfide in eructations and respiration as a contributory cause for high-positive sulfur balances (Table 2). However, the sulfur retention values were not closely related to the sulfur intakes of the cows. Although the sulfur intake of 0 -cow Voona during trial II was $81 \%$ greater than during the Voona I trial, a slightly decreased retention value was obtained in trial II (Table 2).

Urinary sulfur, as a proportion of the total excreted sulfur, was greater on 0 -feed than on ULP-feed (Table 4), and of the urinary sulfur of 0-, ULPand NorP-cows, inorganic sulfates accounted for $87-90,70-73$ and $20-87 \%$ respectively. Also in faeces the proportion of inorganic sulfate sulfur of the total sulfur was greater on 0 -feed than on ULP- or NorP-feed. The content of inorganic sulfates in urine is related to the sulfur content of the feed. The sulfur contents of 0 - and ULP-feeds were approximately equal (Table 1), and the contents and proportions of the sulfur fractions in the urine of NorPcows (Table 3 ) indicate that at comparable dietary sulfur levels these cows excrete less sulfur as inorganic sulfates than 0 -cows. The N:S ratio in the urine of 0 -cows ranged from 1.7 to 9.8 , and in the urine of ULP-cow Euru it was 10 during both trials. In the faeces of 0 - and ULP-cows this ratio was $20-24$ and $9.6-9.7$ respectively. The increased urinary excretion of inorganic sulfates is obviously a result of the increased absorption of hydrogen sulfide from the rumen. 
Table 4. Proportion of urinary, faecal and milk sulfur of the total excreted sulfur during balance trials with 0 - and ULP-cows.

\begin{tabular}{|c|c|c|c|c|}
\hline \multicolumn{2}{|c|}{$\begin{array}{l}\text { Cow and } \\
\text { number } \\
\text { of trial }\end{array}$} & \multirow[t]{2}{*}{$\begin{array}{l}\text { Urinary sulfur, } \\
\% \text { of excreted } \\
\text { sulfur }\end{array}$} & \multirow[t]{2}{*}{$\begin{array}{l}\text { Faecal sulfur, } \\
\% \text { of excreted } \\
\text { sulfur }\end{array}$} & \multirow[t]{2}{*}{$\begin{array}{l}\text { Milk sulfur, } \\
\% \text { of excreted } \\
\text { sulfur }\end{array}$} \\
\hline 0 -cow & Oona: & & & \\
\hline I & ............. & 62.5 & 16.9 & 20.6 \\
\hline II & …................... & 72.5 & 16.2 & 11.3 \\
\hline III & 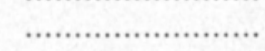 & 54.8 & 24.1 & 21.1 \\
\hline IV & 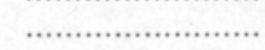 & 63.8 & 22.4 & 13.8 \\
\hline $\mathrm{v}$ & ………................ & 73.7 & 14.7 & 11.6 \\
\hline \multicolumn{5}{|c|}{ 0-cow Voona: } \\
\hline I & 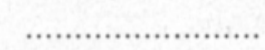 & 61.0 & 20.8 & 18.2 \\
\hline II & ........................... & 76.6 & 14.4 & 9.0 \\
\hline \multicolumn{5}{|c|}{ ULP-cow Euru: } \\
\hline I & 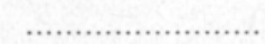 & 53.0 & 32.5 & 14.5 \\
\hline II & 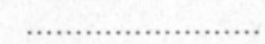 & 51.5 & 35.0 & 13.4 \\
\hline
\end{tabular}

Ester sulfate sulfur as a proportion of the urinary and faecal sulfur was less on 0 -feed than on ULP- or NorP-feed (Tables 2 and 3). The extent of ester sulfate sulfur excretion depends on the activity of the microorganisms in the rumen and intestines, but the higher excretion rate of ester sulfates by ULPand NorP-cows may be due also to the greater amounts of phenols, sterols and heterocyclic compounds in their feed. It should be noted that on ordinary feed too the urinary ester sulfate excretion of cows fluctuates so much (KNAPPEN 1959) that the low 0 -cow values found in this study are within this range.

Urinary neutral sulfur averaged $7.9 \%$ of the total urinary sulfur for 0 cows and $11 \%$ for ULP- and NorP-cows. In faeces, neutral suluur comprised 81,82 and $93 \%$ of the faecal sultur of 0 -, ULP- and NorP-cows respectively. The decreased neutral sulfur outputs of 0 -cows point to a defective utilization of sulfate sulfur for protein synthesis in the rumen.

\section{Sulfur in blood, plasma and milk}

The sulfur contents of blood, plasma and milk of cows on the different feeds were quite similar (Table 5). As reported in the literature (DIEM and LENTNER 1971), the sulfur content of bovine milk ranges from 0.24 to 0.36 $\mathrm{mg} / \mathrm{ml}$. Thus we obtained normal values for the total sulfur content of the milk samples in this study. In contrast, the total sulfate sulfur contents in the milk of the test cows were slightly low. The sulfur contents in the blood of the cows were higher than those reported by JACOBSon et al. (1967).

\section{Sulfur in rumen fluid}

The sulfur content in rumen fluid is a measure of how much sulfur is available to the rumen microorganisms for the synthesis of new proteins. The results (Fig. 2) show that the rumen bacteria of 0 -cow Oona reduced sulfate 
Table 5. Sulfur contents in milk, blood and plasma of cows on 0-, ULP- or NorP-feed. The number of samples is indicated in parentheses and the range of values below the means.

\begin{tabular}{|c|c|c|c|c|c|c|c|}
\hline \multirow[b]{2}{*}{ Feed } & \multirow[b]{2}{*}{$\begin{array}{l}\text { No. of } \\
\text { cows }\end{array}$} & \multicolumn{3}{|c|}{ Total sulfur } & \multicolumn{3}{|c|}{ Total sulfate sulfur } \\
\hline & & $\begin{array}{l}\text { Milk } \\
\mathrm{mg} / \mathrm{g}\end{array}$ & $\begin{array}{l}\text { Blood } \\
\mathrm{mg} / \mathrm{ml}\end{array}$ & $\begin{array}{r}\text { Plasma } \\
\mathrm{mg} / \mathrm{ml}\end{array}$ & $\begin{array}{l}\text { Milk } \\
\mathrm{mg} / \mathrm{g}\end{array}$ & $\begin{array}{l}\text { Blood } \\
\mathrm{mg} / \mathrm{ml}\end{array}$ & $\begin{array}{l}\text { Plasma } \\
\mathrm{mg} / \mathrm{ml}\end{array}$ \\
\hline 0 & 2 & $\begin{array}{ll}0.36 & (8) \\
0.34 & -0.39\end{array}$ & $\begin{array}{ll}1.24 & (8) \\
1.13-1.35\end{array}$ & $\begin{array}{l}1.06 \quad(6) \\
1.03-1.08\end{array}$ & $\begin{array}{l}0.027 \quad(8) \\
0.021-0.032\end{array}$ & $\begin{array}{l}0.105 \quad(8) \\
0.078-0.138\end{array}$ & $\begin{array}{l}0.278 \quad(6) \\
0.255-0.304\end{array}$ \\
\hline ULP & 4 & $\begin{array}{l}0.33 \quad(6) \\
0.30-0.36\end{array}$ & $\begin{array}{l}1.32 \quad(9) \\
1.08-1.52\end{array}$ & $\begin{array}{ll}1.11 & (6) \\
1.05-1.15\end{array}$ & $\begin{array}{l}0.033 \quad(6) \\
0.029-0.036\end{array}$ & $\begin{array}{l}0.111 \quad(9) \\
0.083-0.131\end{array}$ & $\begin{array}{l}0.310 \quad(6) \\
0.294-0.328\end{array}$ \\
\hline NorP & 6 & & $\begin{array}{l}1.23 \quad(6) \\
1.18-1.36\end{array}$ & $\begin{array}{l}1.06 \quad(4) \\
1.03-1.13\end{array}$ & & $\begin{array}{l}0.116 \quad(6) \\
0.103-0.130\end{array}$ & $\begin{array}{l}0.318 \quad(4) \\
0.307-0.340\end{array}$ \\
\hline
\end{tabular}

sulfur efficiently. Six hours after the start of feeding, the sulfate sulfur contents in the rumen of Oona were, on the days of study, so low that they may have limited bacterial growth. In considering the results, it should be remembered that our analytical method for sulfate sulfur may have been somewhat unreliable with rumen fluid.

\section{Nutritional value of inorganic sulfates as sulfur sources in 0 -feed}

Although 0-cow Voona during the second balance trial consumed $81 \%$ more sulfur daily than during its first trial, its milk production increased only $0.6 \%$. The increased excretion of inorganic sulfate in urine and faeces ensued from the increased sulfur (and dry matter) intake. This result as well as the low content of methionine and other amino acids in the blood plasma of 0 cows (VIRTANEN et al. 1972) seem to be indications of a somewhat limited utilization of sulfate sulfur or urea and ammonium nitrogen in protein synthesis in the rumen of these cows. MAENG and BALDwin (1976) have reported that the addition of small amounts of amino acids to a diet containing urea as the sole nitrogen source improved rumen microbial yields considerably. McMeniman et al. (1976) in turn have recently shown that the extent of direct incorporation of sulfur-containing amino acids by rumen microbes may be greater than has been generally believed. Besides, part of the dietary protein may pass undigested out of the rumen (Thомas 1975). However, no changes were observed in the low contents of certain free amino acids in the plasma of 0 -cows when methionine hydroxy analogue or purified proteins were added to their diets (MÄKINEN 1972). So possibly a suitable amount of other ingredients of normal feed would be needed to supplement the 0-diet for correctly balanced functioning of the rumen microbes. For example, fineness may be one fault of 0 -feed.

A high level of dietary sulfur can be deleterious to cattle. Elam (1975) warns against using more than $0.3 \%$ sulfur in the rations for cattle, but Westermann et al. (1975) place the limit at $0.5 \%$ sulfur. The feeding of elemental sulfur to 0 -cows caused the formation of malodorous sulfur compounds in the rumen, followed by the death of some of the animals (VIRTANEN et al. 1972); the total sulfur content of the feed slightly exceeded $0.4 \%$ during these 


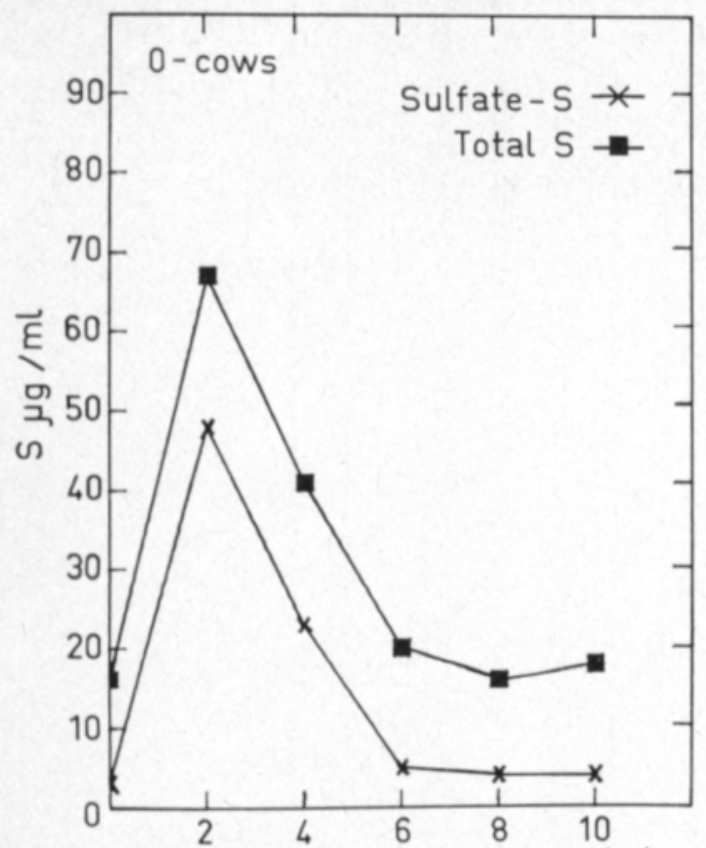

Time after starting feeding $(\mathrm{h})$
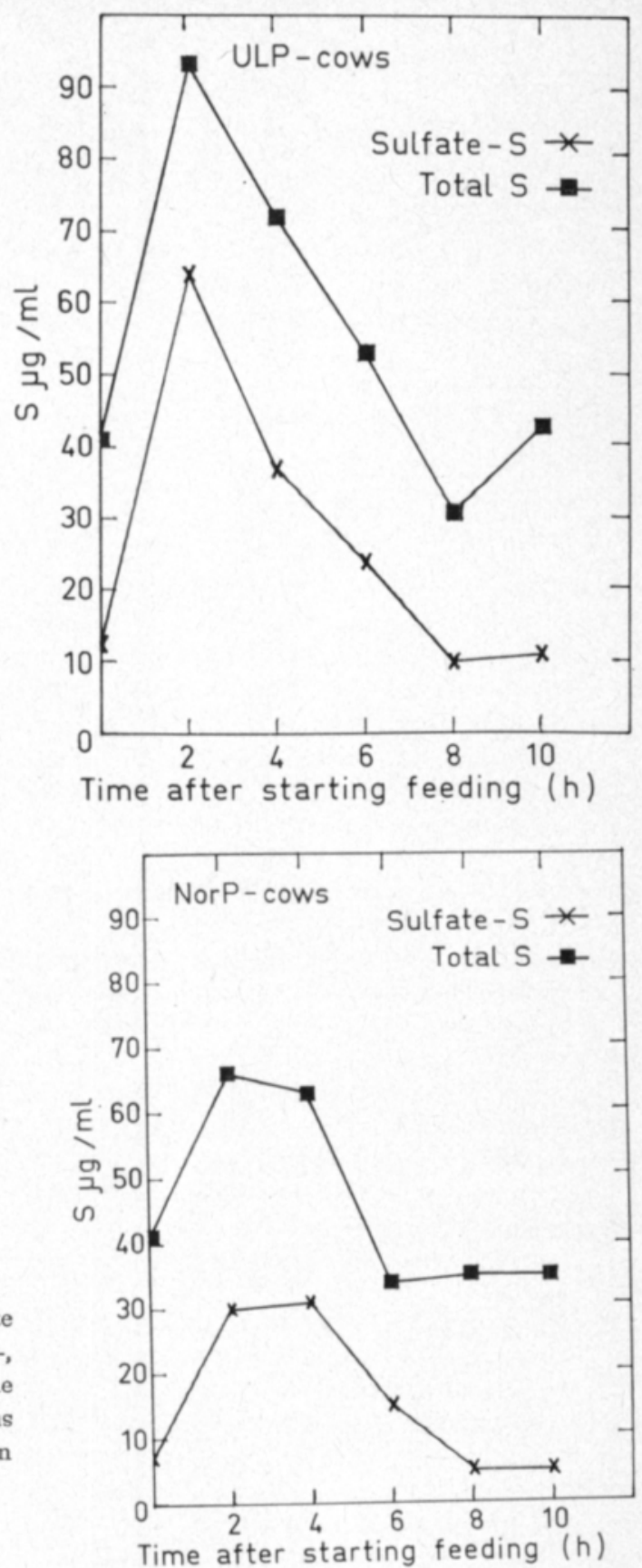

Time after starting feeding ( $h$ )

Figure 2. Total sulfur and total sulfate sulfur contents in the rumen fluid of $\mathbf{0}$-, ULP- and NorP-cows as a function of time after starting feeding. The values are means of analyses made on samples collected on two different days.

tests. However, a contributory cause of death may have been a deficiency of vitamin E. No clear toxicity symptoms appeared in the 0 -cows after the addition of this vitamin to their diets.

During the balance trials with 0 -cow Voona the sulfur contents of the feed were 0.22 and $0.27 \%$ of the dry matter. Although the intake of feed was greater during the latter trial, no clear correlation between the appetite of the 0 -cows and the sulfate sulfur content in their feed $(0.22-0.40 \%$ sulfur of dry matter) has been observed during the feeding experiments. However, 
the reduced appetite of the 0 -cows during the main milk production period may have been due to slight sulfide poisoning. A fairly large sulfate content in their feed may have caused too rapid a generation of sulfide in relation to its utilization for protein synthesis by the rumen microbes. Observations that the supplementation of feeds with sulfates can produce a depression in feed intake in cows and sheep (Elam 1975, Graham et al. 1976) gives support to this supposition.

Acknowledgement: Our thanks are due to Miss Terttu Ettala, M. Agr. Sci., for the details of the feed and nitrogen excretion of the 0 - and ULP-cows.

\section{REFERENCES}

BiRD, P. R. \& Fountain, R. D. 1970. A method for the determination of sulphur in some biological materials. Analyst (London) 95: 98-102.

Bray, A. C. \& TILL, A. R. 1975. Metabolism of sulphur in the gastro-intestinal tract. In: Digestion and Metabolism in the Ruminant. Proceedings of the IV International Symposium on Ruminant Physiology. Sydney, Australia, August 1974 (I. W. McDonald and A. C. I. Warner, eds) pp 243-260. The University of New England Publishing Unit, Armidale.

Diem, K. \& Lentner, C. 1971. Scientific Tables, 7th edn. p 688. Ciba-Geigy Limited, Basle, Switzerland.

Elam, C. J. 1975. Sulfur requirement of ruminant. Feedstuffs 47: 23-25, 48.

Ettala, T. \& Kreula, M. 1976. Milk production on low-protein, urea-rich feed. Acta Agr. Scand. 26: 33-39.

Graham, C. A., Warner, R. B. \& Jenkins, S. L. 1976. An evaluation of ammonium sulphate as a potential NPN source for ruminants. Australian J. Exp. Agr. Animal Husbandry 16: $838-844$.

Homer, D. R. \& Virtanen, A. I. 1973. Bovine blood plasma lipids: depressed levels in cows on protein-free feed. Milchwissenschaft 28: 546-550.

Jacobson, D. R., Barnett, J. W., CarR, S. B. \& Hatton, R. H. 1967. Voluntary feed intake, milk production, rumen content, and plasma-free amino acid levels of lactating cows on low sulfur and sulfur-supplemented diets. J. Dairy Sci. 50: 1248-1254.

KNappen, F. 1960. Gesamt-, Neutral-, Ester- und Sulfat-Schwefel im Harn von Hammels und Milchkühen bei verschiedener Fütterung. Z. Tierphysiol. Tierernähr. Futtermittelk. 15: 119-127.

MaENG, W. J. \& Baldwin, R. L. 1976. Factors influencing rumen microbial growth rates and yields: effect of amino acid additions to a purified diet with nitrogen from urea. J. Dairy Sci. 59: 648-655.

MÃKINEN, S. 1972. Aspects of the nitrogen metabolism and nutritional status of urea-fed dairy cattle. Ann. Acad. Sci. Fenn. Ser. A 2 No 165, p 35.

McMeniman, N. P., Ben-Ghedalia, D. \& Elliott, R. 1976. Sulphur and cystine incorporation into rumen microbial protein. Brit. J. Nutr. 36: 571-574.

Tномлs, P.C.1975. Diet and milk secretion in the ruminant. World Rev. Anim. Prod. 11:33-44.

Virtanes, A. I. 1967. Milk production on a protein-free and protein-poor feed. Neth. Milk Dairy J. 21: 223-244.

- - , EtTAla, T. \& MÄKinen, S. 1972. Milk production of cows on purified protein-free feed

with urea and ammonium salts as the only nitrogen source and on non-purified feed with rising amounts of true protein. In: Festskrift til Prof. Dr. Agr. h.c. Knut Breirem til hans 70-års dag, pp 249-276. Mariendals Boktrykkeri A.s. Gjøvik.

Westermann, H. D., Thalmann, A. \& Kummer, H. 1975. Uber die Toxizität von Schwefelwasserstoff in der Tierfütterung. Eine Literaturstudie. Landwirtsch. Forsch. 28: 70-80.

Whanger, P. D. 1972. Sulfur in ruminant nutrition. World Rev. Nutr. Dietet. 15: 225-255.

Ms received September 28, 1977. 


\section{SELOSTUS}

\section{Tutkimuksia proteiinitonta tai vähäproteiinista rehua syövien lehmien rikkiaineenvaihdunnasta}

\section{Eino Matrkkala ja Matti Kreula}

Biokemiallinen Tutkimuslaitos, Kalevankatu 56 b, 00180 Helsinki 18.

Puhdasrehun, jossa proteiini oli korvattu urealla ja ammoniumsuoloilla (0-rehu), sekä puhdistamattoman, runsaasti ureaa ja vähän proteiinia sisältävän rehun (ULP-rehu) vaikutusta lehmien rikkiaineenvaihduntaan on tutkittu määrittämällä eri rikkifraktioiden pitoisuuksia lannoista, virtsoista, maidoista, veristä ja pötsinesteistä. 0-rehussa rikki oli yksinomaan epäorgaanisina sulfaatteina. Tasekokeissa rehuissa typen suhde rikkiin vaihteli $6.1-9.5$ ja rikkipitoisuus $0.22-0.31 \%$ kuiva-aineesta. Jokaisena viiden tai seitsemän vuorokauden pituisena koejaksona (seitsemän koejaksoa 0- ja kaksi ULP-ruokinnalla) lehmien rikkitaseet olivat hyvin positiiviset. Virtsassa erittyneen rikin osuus rikin kokonaiserityksestä oli 0-lehmillä suurempi kuin ULPlehmillä. Epäorgaanisen sulfaattirikin osuus virtsan ja lannan kokonaisrikistä oli 0-lehmillä suurempi kuin ULP- tai NorP-lehmillä (tavanomaista proteiinirikasta rehua syövät lehmät), mutta esterisulfaatti- ja neutraalirikin osuuksien suhteen asia oli päinvastoin. Maidon ja veren rikkipitoisuuksissa ei eri ruokinnoilla ilmennyt oleellisia eroja.

Ruokinnan aloittamisen jälkeen sulfaattipitoisuus kohosi 0-lehmien pötsinesteessä nopeasti ja laski sitten taas varsin nopeasti. Otaksumme, että 0-lehmien pötsin bakteerit saattavat muodostaa rikkivetyä niin nopeasti, ettei se tule kokonaisuudessaan käytetyksi rikkiyhdisteiden synteesiin, vaan huomattava osa siitä poistuu röyhtäisyissä tai erittyy absorption jälkeen epäorgaanisina sulfaatteina virtsassa. 